\title{
Análise da vulnerabilidade na zona de amortecimento do Parque Estadual do Ibitipoca (MG), com o uso de SIG
}

\author{
Taiana Evangelista dos Reis ${ }^{*}$ \\ Vivian Castilho da Costa**
}

\section{Resumo}

As áreas de preservação permanente (APPs) são protegidas no Brasil através da Lei ${ }^{\circ} 12.651$, de 25 de maio de 2012 (Novo Código Florestal) e, independentemente de sua localização, devem ser conservadas, com intuito de manter a biodiversidade e os recursos naturais. $\mathrm{O}$ entorno de uma Unidade de Conservação é denominado zona de amortecimento (SNUC, 2000) e as atividades nela são restritas. A zona de amortecimento (ZA) do Parque Estadual do Ibitipoca, localizado em Minas Gerais, possui 38,45 $\mathrm{Km}^{2}$ de APPs. O presente trabalho visa estudar e mapear a vulnerabilidade ambiental das APPs presentes na ZA do Parque Estadual do Ibitipoca, utilizando o Sistema de Informação Geográfica (SIG). Os resultados permitem apontar as áreas mais impactadas, decorrentes de explorações inadequadas no uso da terra e em áreas de solos e declividade não compatíveis com a proteção dos recursos naturais existentes.

Palavras-chave: Vulnerabilidade ambiental; Áreas de preservação permanente; Zona de amortecimento; Parque Estadual do Ibitipoca; SIG.

* Doutoranda em Geografia, Universidade do Estado do Rio de Janeiro (taiana.geo@gmail.com).

*** Departamento de Geografia Física, Universidade do Estado do Rio de Janeiro (vivianuerj@gmail.com).

Geosul, Florianópolis, v. 32, n. 63, p 77-96, jan./abr. 2017 
REIS, T.E. dos \& COSTA, V.C. da. Análise da vulnerabilidade na zona ...

Analysis of environmental vulnerability in the buffer zone of Ibitipoca State Park (MG), using GIS

\begin{abstract}
The permanent preservation areas are protected in Brazil by Law number 12,651, of May 25, 2012 (New Forest Code) and, regardless of their location, must be preserved, with the aim of maintaining biodiversity and natural resources. The surroundings of a Conservation Unit is referred to as a buffer zone and activities in them are restricted. The buffer zone of Ibitipoca State Park, located in Minas Gerais State, has 38.45 square kilometers of permanent preservation areas. This work aims to study and map the environmental vulnerability of permanent preservation areas, present in the buffer zone of Ibitipoca State Park, using Geographic Information System (GIS). The results allowed to point out the most impacted areas, resulting from inadequate holdings in land use and areas of soils and slope not compatible with the protection of natural resources.
\end{abstract}

Key word: Environmental vulnerability; Permanent preservation areas; Buffer zone; Ibitipoca State Park; GIS.

\title{
Introdução
}

Conservar as últimas florestas tropicais brasileiras vem sendo prioridade do governo, que, cada dia mais, preocupa-se com o número de áreas sob proteção legal. O Brasil possui diversas Unidades de Conservação (UCs), que são essenciais para a manutenção da biodiversidade.

$\mathrm{O}$ manejo e a conservação dessas áreas têm sido um dos grandes problemas para os administradores, pois as interferências ocasionadas pela população do entorno das UCs vêm projetando impactos sobre as Unidades. Diante da situação, foram criadas normas a fim de minimizar o avanço desses impactos. 
REIS, T.E. dos \& COSTA, V.C. da. Análise da vulnerabilidade na zona ...

A Resolução CONAMA (1990) estabeleceu a necessidade da definição de zonas de amortecimento no entorno de UCs com o propósito de reduzir os impactos sobre as áreas protegidas. $\mathrm{O}$ SNUC, em 2000, contribuiu com a sistematização e a consolidação dos conceitos associados às UCs, e também estabeleceu regras para a elaboração dos limites das zonas de amortecimento (ZA) (BRASIL, 1990).

A zona de amortecimento ou zona tampão está localizada no entorno da Unidade de Conservação, e é determinada com intuito de filtrar os impactos negativos das atividades externas a ela, como poluição, barulho, aparição de espécies exóticas e o avanço da ocupação humana (MILLER, 1997).

As áreas de preservação permanente são protegidas por lei, que devem ser preservadas independentemente de sua localização. A Resolução CONAMA n ${ }^{\text {o: }}$ 303, de 20 de março de 2002 (BRASIL, 2002), afirma que se devem proteger as áreas situadas:

\begin{abstract}
"em uma faixa de trinta metros, para o curso d’água com menos de dez metros de largura; (...) ao redor de nascente ou olho d água, ainda que intermitente, com raio mínimo de cinquenta metros; (...) no topo de morros e montanhas, em áreas delimitadas a partir da curva de nível correspondente a dois terços da altura mínima da elevação em relação à base; nas linhas de cumeada, em área delimitada a partir da curva de nível correspondente a dois terços da altura, em relação à base, do pico mais baixo da cumeada, fixando-se a curva de nível para cada segmento da linha de cumeada equivalente a mil metros; em encosta ou parte desta, com declividade superior a cem por cento ou quarenta e cinco graus na linha de maior declive.” (BRASIL, 2002)
\end{abstract}

Em 2012, o Novo Código Floresta, lei no 12.651 de 25 de maio (BRASIL, 2012), redefiniu as normas para a delimitação das áreas de preservação permanente, considerando assim, APPs: 
REIS, T.E. dos \& COSTA, V.C. da. Análise da vulnerabilidade na zona ...

- As faixas marginais de qualquer curso d'água natural em largura mínima de 30 (trinta) metros, para os cursos d'água de menos de 10 metros de largura (...);

- áreas no entorno das nascentes e dos olhos d'água perenes, com raio mínimo de 50 metros; (...)

- encostas com declividade superior a $45^{\circ}$, equivalente a 100 na linha de maior declive; (...)

- no topo de morros, montes, montanhas e serras, com altura mínima de 100 metros e inclinação média maior que $25^{\circ}$, as áreas delimitadas a partir da curva de nível correspondente a $2 / 3$ (dois terços) da altura mínima da elevação sempre em relação à base, sendo esta definida pelo plano horizontal determinado por planície ou espelho d'água adjacente ou, nos relevos ondulados, pela cota do ponto de sela mais próximo à elevação;

- as áreas em altitude superior a 1.800 metros; (...)

A grande diferença do Novo Código Florestal, de 2012, em relação à resolução CONAMA de 2002, está na delimitação do topo de morros. Aquele estabelece a altura mínima de 100 metros e a inclinação média maior que $25^{\circ}$, com áreas delimitadas a partir da curva de nível correspondente a $2 / 3$ da altura mínima em relação à base.

Mesmo protegidas por Lei, as APPs tornam-se áreas vulneráveis aos impactos do homem, devido à falta de preservação e à exploração inadequada da terra.

A vulnerabilidade é definida, geralmente, como uma situação na qual estão presentes três componentes: exposição ao risco, incapacidade de reação e dificuldade de adaptar-se após a materialização do risco (Moser, 1998 apud ALVES, 2006).

Acselrad (2010) afirma que a vulnerabilidade está associada à exposição aos riscos e indica uma maior ou menor suscetibilidade de lugares, pessoas, infraestruturas ou escossistemas sofrerem algum agravo. A vulnerabilidade ambiental está relacionada às características do meio físico e biótico, tais como declividade, altitude, temperatura, aridez, vegetação e solo, além da exposição a 
REIS, T.E. dos \& COSTA, V.C. da. Análise da vulnerabilidade na zona ...

fontes de pressão ambiental e à existência de impactos ambientais (Li et al., 2006).

O geoprocessamento é uma ferramenta que auxilia na medição dos impactos, possibilitando a obtenção, o armazenamento e o processamento dos dados. Com ele, é possível individualizar cada "espaço, de forma mais confiável, discernir e explicar os fenômenos que ocorrem, permitindo processar informações confiáveis, precisas e rapidamente acessíveis" (Veiga, 1999 apud RIBEIRO, 2013).

Portanto, o uso de técnicas de geoprocessamento irá auxiliar o presente trabalho a identificar as áreas de vulnerabilidade ambiental nas APPs localizadas na zona de amortecimento do Parque Estadual do Ibitipoca.

\section{Objetivo}

O presente trabalho visa caracterizar a vulnerabilidade ambiental, utilizando técnicas de geoprocessamento, nas áreas de preservação permanente da zona de amortecimento do Parque Estadual do Ibitipoca, localizado no estado de Minas Gerais. Os processos adotados nesta pesquisa permitirão a geração de um banco de dados georreferenciado e os resultados apoiarão a tomada de decisão dos gestores.

\section{Área de estudo}

O Parque Estadual do Ibitipoca (PEI) pertence aos municípios de Lima Duarte e Santa Rita de Ibitipoca, no Estado de Minas Gerais. Sua área é de $14.887 \mathrm{~m}^{2}$ e a entrada principal está localizada aproximadamente três quilômetros do distrito de Conceição do Ibitipoca e tendo sido criado em 1973, pelo Governo de Minas Gerais, através de Lei Estadual nº 6.126.

Localizado na Serra da Mantiqueira, o Parque Estadual do Ibitipoca é considerado um divisor de água, pois separa as bacias do Rio Grande e do Rio Paraíba do Sul. Atualmente é uma 
REIS, T.E. dos \& COSTA, V.C. da. Análise da vulnerabilidade na zona ... importante Unidade de Conservação para a região, na qual as espécies nativas do estado de Minas Gerais são protegidas (BEDIM, 2008).

A zona de amortecimento do Parque Estadual do Ibitipoca foi estabelecida em 2006, através do primeiro Plano de Manejo. Com uma área de aproximadamente $100,41 \mathrm{~km}^{2}$, a ZA abrange o entorno do Parque que pertence aos municípios de Lima Duarte, Santa Rita do Ibitipoca e Bias Fortes (Figura 1).

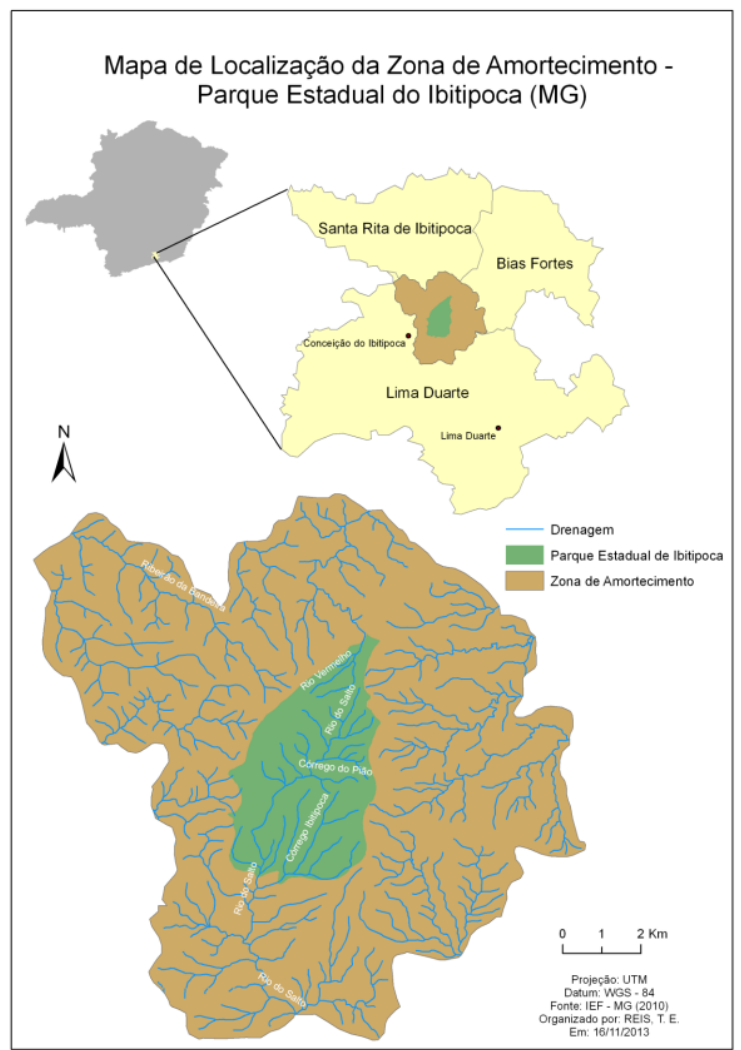

Figura 1: Mapa de Localização da zona de amortecimento. Fonte: IEF - MG (2010) 
REIS, T.E. dos \& COSTA, V.C. da. Análise da vulnerabilidade na zona ...

No entorno do PEI, a população vive da agricultura de subsistência, com pequenas plantações e criação de animais. A fim de ampliar a renda familiar, algumas dessas famílias também produzem quitandas e as vendem para os turistas, entre elas podemos destacar o típico pão folhado, conhecido também como pão de canela.

Portanto, as principais atividades da Vila Conceição do Ibitipoca, responsáveis por mover a economia local, são o comércio, o artesanato e o turismo.

De acordo com estudo realizado pela Universidade Federal de Viçosa (2010), o tipo de solo predominante na ZA é classificado como CXbd33 (Cambissolo háplico 40\% + latossolo vermelhoamarelo $30 \%$ + cambissolo húmico 30\%). Também, em grande quantidade, são encontrado o CXbd1 (cambissolo háplico) e o CXbd7 (cambissolo háplico + latossolo vermelho). Próximo à divisa do parque o solo é composto por neossolo litólico e afloramento rochoso. Em pequenas partes, dentro da ZA, encontram-se latossolo vermelho-amarelo e cambissolo húmico e suas variações (UFV, 2010).

O relevo no Parque e na ZA é bem acentuado e possui altitudes que variam de 800 a 1780 metros. No entorno do PEI, a morfologia é caracterizada por "morros, colinas, formas intermediárias e vales em $\mathrm{V}$, que pertencem ao Planalto de Andrelândia, com relevos desenvolvidos em rochas metassedimentares do Grupo Andrelândia e à Depressão de Belo Horizonte, desenvolvida localmente em rochas do Gnaisse Piedade" (RODELA, 1998, p.166).

Através do mapeamento do uso e ocupação da terra (utilizando imagem RapidEye e edição vetorial no ArcGS 10.1 por interpretação visual), foi possível perceber que a zona de amortecimento é composta, em sua maioria, por pastagem. Isso ocorre porque a população que ali vive utiliza a pecuária como forma de subsistência. 
REIS, T.E. dos \& COSTA, V.C. da. Análise da vulnerabilidade na zona ...

A mata também é encontrada em grandes extensões, em aproximadamente $33 \%$ de toda a ZA, e $14 \%$ encontram-se com mata em processo de regeneração.

Apesar de ser proibido o plantio de eucalipto na zona de amortecimento do PEI, isso vem ocorrendo em algumas localidades; cerca de $1,36 \%$ da área estudada é plantação de eucalipto. A presença de quartizito em decomposição na região é constante, com $1,5 \%$ de toda ZA.

Também foi constatada a presença de solo exposto, $0,08 \%$, corpos hídricos, 0,04\%, plantações, $0,15 \%$ e áreas construídas, $0,12 \%$ sendo essas compostas por casas, ranchos e currais.

\section{Metodologia}

A primeira etapa da metodologia constituiu-se da coleta, análise e levantamento de dados cartográficos, digitais, imagens e bibliográficos da área. Em seguida, foram realizadas a seleção e a definição do material cartográfico e escala de análise. O Instituto Estadual de Florestas (IEF) disponibilizou para a pesquisa os arquivos em shapefile do limite do Parque Estadual do Ibitipoca, as curvas de níveis e a hidrografia da área em estudo, além da imagem de satélite RapidEye, com uma resolução de 5 metros, do ano de 2009/2010.

As bases utilizadas no mapa pedológico na escala de 1:50.000 foram cedidas pelo Departamento de Solo da Universidade Federal de Viçosa (UFV).

O programa ArcGIS 10.1 foi utilizado no mapeamento. Os primeiros mapas confeccionados foram de localização, declividade, tipos de solo e uso e ocupação da terra.

A divisão das classes da declividade foi determinada a partir das Leis Federais 6.766/1979 e 12.651/2012 e se definiu em: 0-5\%, $5-10 \%, 10-20 \%, 20-30 \%, 30-47 \%, 47-100 \%$ e $>100 \%$.

Os polígonos do mapa de uso e ocupação da terra foram vetorizados através da interpretação da imagem RapidEye e foram divididos nas seguintes categorias: pastagem, plantação, eucalipto, 
REIS, T.E. dos \& COSTA, V.C. da. Análise da vulnerabilidade na zona ...

área construída, quartizito em decomposição, corpos hídricos, mata, mata em regeneração e solo exposto.

A metodologia usada para a confecção dos mapas de vulnerabilidade ambiental foi análise multicritério, a qual se baseia na lógica básica da construção de um SIG. Moura (2007), em seu estudo, apresentou um roteiro metodológico, com base no SIG, dos procedimentos em relação à análise multicritério:

... "[1] seleção das principais variáveis que caracterizam um fenômeno, já realizando um recorte metodológico de simplificação da complexidade espacial; [2] representação da realidade segundo diferentes variáveis, organizadas em camadas de informação; [3] discretização dos planos de análise em resoluções espaciais adequadas tanto para as fontes dos dados como para os objetivos a serem alcançados; [4] promoção da combinação das camadas de variáveis, integradas na forma de um sistema, que traduza a complexidade da realidade; finalmente, [5] possibilidade de validação e calibração do sistema, mediante identificação e correção das relações construídas entre as variáveis mapeadas." (MOURA, op. cit., p. 2900).

O mapa de vulnerabilidade ambiental foi gerado a partir do cruzamento dos planos de informação de declividade, pedologia e uso e ocupação da terra, a cada um foram atribuídos pesos de 0 a $100 \%$ e cada classe de mapa temático recebeu notas que variaram entre 0 a 10. As notas foram escolhidas de acordo com a relevância de cada classe e reclassificadas em vulnerabilidades baixa, média e alta (Figura 2).

Foi utilizado o comando Raster Calculator para realizar a junção dos três mapas. Cada nota do mapa de suscetibilidade foi reagrupada e recebeu classes qualitativas. Esse mapa foi dividido em classes de baixa (de 1 à 4), média (de 4 à 7) e alta (de 7 à 10) vulnerabilidades ambientais. 
REIS, T.E. dos \& COSTA, V.C. da. Análise da vulnerabilidade na zona ...

\begin{tabular}{|l|c|}
\hline \multicolumn{2}{|c|}{ Uso e ocupação da terra- peso: } \\
\hline Classificação & Notas \\
\hline Corpo hídrico & 1 \\
\hline Mata & 3 \\
\hline Mata em regeneração & 4 \\
\hline Pastagem & 6 \\
\hline Área construída & 6 \\
\hline Plantação & 7 \\
\hline Areal & 7 \\
\hline Eucalipto & 8 \\
\hline Solo exposto & 10 \\
\hline
\end{tabular}

\begin{tabular}{|l|c|}
\hline \multicolumn{2}{|c|}{ Declividade - peso: $35 \%$} \\
\hline Classificação & Notas \\
\hline $0 \%-5 \%$ & 1 \\
\hline $5 \%-10 \%$ & 2 \\
\hline $10 \%-20 \%$ & 4 \\
\hline $20 \%-30 \%$ & 5 \\
\hline $30 \%-47 \%$ & 6 \\
\hline $47 \%-100 \%$ & 8 \\
\hline$>100 \%$ & 10 \\
\hline
\end{tabular}

\begin{tabular}{|l|c|}
\hline \multicolumn{2}{|c|}{ Tipos de Solos - peso: 30\% } \\
\hline Classificação & Notas \\
\hline Cambissolo Háplico & 8 \\
\hline $\begin{array}{l}\text { Cambissolo Háplico + Latossolo Vermelho-Amarelo + } \\
\text { Cambissolo Húmico }\end{array}$ & 7 \\
\hline Cambissolo Háplico + Latossolo Vermelho & 10 \\
\hline $\begin{array}{l}\text { Neossolo Litólico + Afloramento de Rocha + Cambissolo } \\
\text { Húmico }\end{array}$ & 3 \\
\hline $\begin{array}{l}\text { Latossolo Vermelho-Amarelo + Latossolo Vermelho + } \\
\text { Cambissolo Háplico }\end{array}$ & 6 \\
\hline $\begin{array}{l}\text { Cambissolo Húmico + Cambissolo Háplico + Latossolo } \\
\text { Vermelho-Amarelo }\end{array}$ & 8 \\
\hline
\end{tabular}

Figura 2: Tabela de pesos e notas usados na classificação dos mapas ambientais

Fonte: DA AUTORA, 2015.

Para alcançar o objetivo proposto do trabalho, foi elaborado um mapa da área de preservação permanente de toda ZA, a fim de visualizar se as áreas mais vulneráveis são protegidas por Lei. O mapa de APP também foi elaborado no programa ArcGis e teve como base a Lei ${ }^{\circ}$ 12.651, de 25 de maio de 2012 (Novo Código Florestal).

No entanto, ao se traçarem as APPs de topo de morro, encontrou-se uma grande dificuldade e foi preciso buscar 
REIS, T.E. dos \& COSTA, V.C. da. Análise da vulnerabilidade na zona ...

metodologias para auxiliarem na elaboração, mas poucas explicavam como realizar o mapeamento detalhadamente. A exemplo da metodologia de Oliveira e Filho (2013), a qual não foi possível seguir todos os passos por não haver maiores explicações, tornando inviável seguir os procedimentos.

Devido a essa dificuldade optou-se por fazer o mapa de APP de topo de morro seguindo a Resolução CONAMA n ${ }^{\text {: }}$ : 303, de 20 de março de 2002 (BRASIL, 2002), que considerava APP "topo de morros e montanhas, em áreas delimitadas a partir da curva de nível correspondente a dois terços da altura mínima da elevação em relação à base".

Para realizar o mapa de APP então, foram utilizados os procedimentos metodológicos sugeridos por Peluzio et al (2010), o qual utiliza o programa ArcGis e tem como base a Resolução CONAMA nº: 303 de 2002. A fim de auxiliar os dados obtidos, foi realizado um clip das áreas de vulnerabilidade ambiental com o mapa de APP, que objetiva verificar as áreas mais vulneráveis que estão dentro das áreas protegidas por lei.

\section{Resultado}

A partir da junção dos mapas de pedologia, declividade e uso e ocupação da terra da ZA, foi possível gerar o mapa de vulnerabilidade ambiental.

O mapa apresentou baixas, médias e altas vulnerabilidades em diversos pontos espalhados na área de estudo (Figura 3). Os resultados possibilitaram identificar que $19 \%$ da ZA estão classificados como alta vulnerabilidade e se encontram em locais com declividade de $47 \%$ a $100 \%$, solos do tipo neossolo litólico, além de áreas com solo exposto e plantações de eucalipto.

As áreas de média vulnerabilidade estão em grande parte da ZA, aproximadamente $58 \%$, e apresentam solos do tipo cambissolo háplicola+latossolo vermelho-amarelo e o cambissolo húmico+Cambissolo háplico+latossolo vermelho-amarelo, 
REIS, T.E. dos \& COSTA, V.C. da. Análise da vulnerabilidade na zona ...

declividades que variam de $10 \%$ a $47 \%$ e o solo ocupado por mata em regeneração, pastagem, área construída, plantação e areal.

Áeas de baixa vulnerabilidade ocupam $23 \%$ da ZA. Nelas são encontrados solos dos tipos latossolo vermelhoamarelo+latosso vermelho+cambissolo háplico, declividades que variam de 0 a $10 \%$, ocupadas por mata e corpos hídricos. As baixas vulnerabilidades estão localizadas predominantemente na porção leste e na oeste do Parque.

As áreas classificadas com alta vulnerabilidade encontramse ao redor do parque, formando uma faixa ao norte e ao leste. Podemos dizer que isso ocorre devido à alta declividade na área, que foi classificada acima de $47 \%$ de declive. Os tipos de solo presentes são neossolo litólico+afloramento de rocha+cambisssolo húmico, além de cambissolo háplico+latossolo vermelhoamarelo+cambisssolo húmico. Próximo ao sul e ao leste, também foi possível encontrar áreas com alta vulnerabilidade, decorrentes da predominância de pastagens (áreas degradadas), associados ao latossolo vermelho-amarelo (alta erodibilidade).

As áreas classificadas como médias e altas vulnerabilidades são encontradas em $77 \%$ da zona de amortecimento. Isso ocorre devido à grande presença de pastagem, às altas declividades e solos suscetíveis à erosão, consideradas como áreas vulneráveis a movimento de massa, a queimadas (provocadas ou em decorrência de combustão espontânea em época de estiagem) e à degradação do solo para lavouras ou agricultura, tornando o manejo da ZA da UC um local de conflitos sócio-econômicos e ambientais.

O mapa da delimitação das áreas de preservação permanente (Figura 4) mostra que $38,45 \mathrm{~km}^{2}$ da zona de amortecimento são áreas protegidas por lei (APP) e deveriam estar preservadas, mesmo que não estivessem dentro da ZA. Essas áreas correspondem a quase $40 \%$ de toda zona de amortecimento.

De acordo com o mapa de APP, as áreas de preservação permanentes correspondem a $38,29 \%$ da ZA. Isso significa que pelo menos essas áreas deveriam estar preservadas mesmo que não estivessem dentro de uma zona de amortecimento. 
REIS, T.E. dos \& COSTA, V.C. da. Análise da vulnerabilidade na zona ...

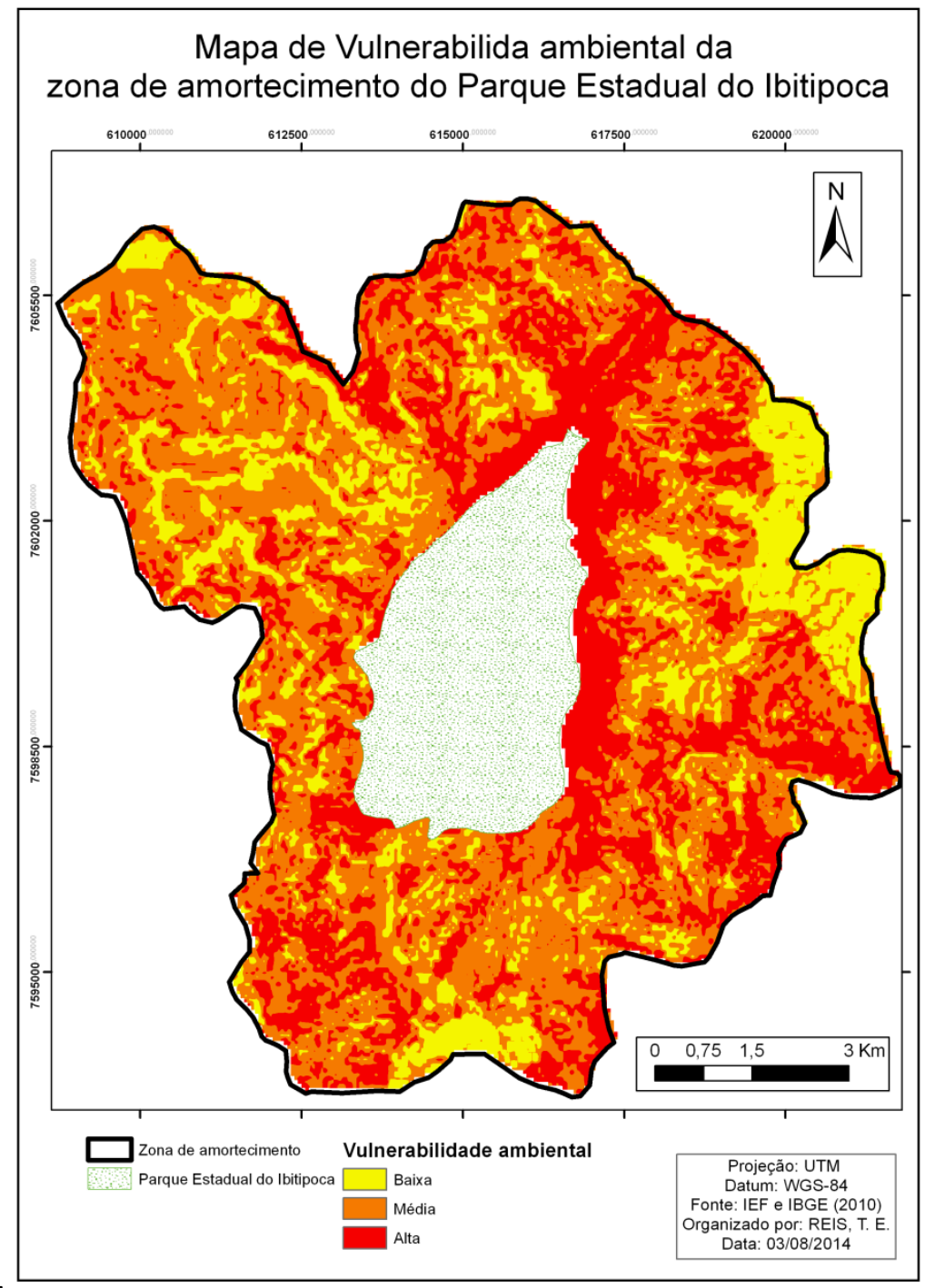

Figura 3: Mapa de Vulnerabilidade ambiental da zona de amortecimento Fonte: IEF e UFV, 2010. 
REIS, T.E. dos \& COSTA, V.C. da. Análise da vulnerabilidade na zona ...

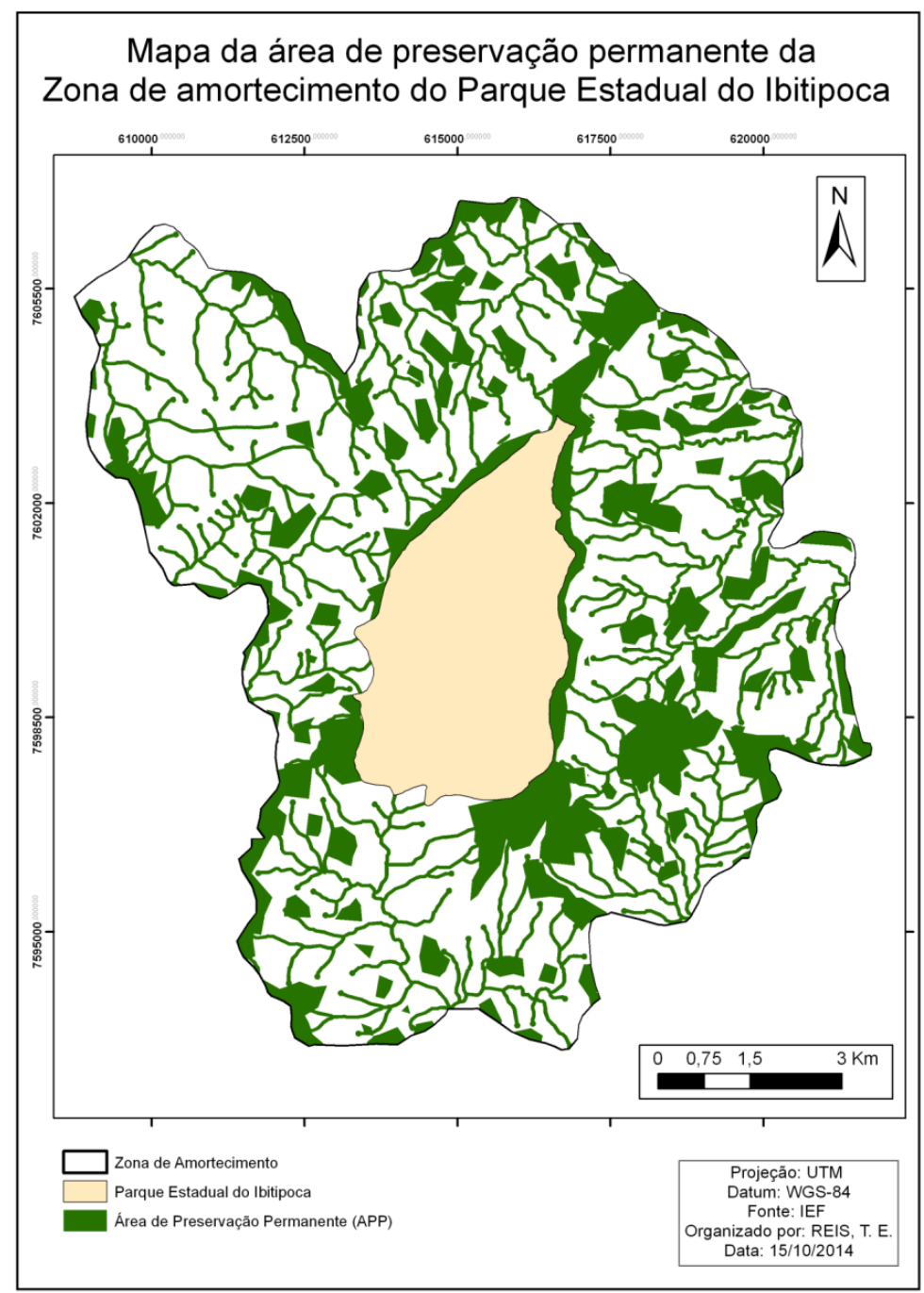

Figura 4: Mapa da área de preservação permanente da zona de amortecimento.

Fonte: IEF , 2010. 
REIS, T.E. dos \& COSTA, V.C. da. Análise da vulnerabilidade na zona ...

O mapa de vulnerabilidade ambiental nas APP (Figura 5) mostra a classificação dessas áreas, onde cerca de $21,64 \%$ estão classificadas como baixa vulnerabilidade ambiental e, apesar de estarem espalhadas por toda a zona de amortecimento, concentramse no lado leste e oeste do Parque. A maioria das áreas de preservação permanente se encontra em média vulnerabilidade, $46,22 \%$, e está localizada em diversas partes da ZA, prevalecendo no sul e no sudeste do PEI. Já as áreas classificadas em alta vulnerabilidade estão presentes em 32, 14\% das APPs e se encontram ao redor do Parque principalmente em sua parte Norte.

\section{Considerações finais}

O presente trabalho buscou estudar e caracterizar a vulnerabilidade ambiental trazida pelo o uso e ocupação da terra, declividade e tipos de solos, utilizando técnicas de geoprocessamento nas áreas de preservação permanente da zona de amortecimento do Parque Estadual do Ibitipoca.

Mediante os dados resultantes, nota-se que mais da metade das APPs foi classificada em média e alta vulnerabilidade. Essas áreas são protegidas por lei e não deveriam ser degradadas.

As áreas classificadas como alta vulnerabilidade ambiental, que se encontram dentro das APPs, devem ser prioridades nos programas de manejo e conservação da zona de amortecimento. Investir na preservação e na conservação dessas áreas ajudará a diminuir a taxa de vulnerabilidade ambiental.

Diante desses dados, entende-se que cabe aos gestores do Parque, ao IEF e às prefeituras dos municípios conscientizar a população de preservar as áreas protegidas por lei e impedir, através de fiscalização, que outras construções sejam realizadas em APPs.

A geração de práticas sustentáveis é um caminho promissor e para sua concretização torna-se necessária a cooperação de agentes do estado e lideranças comunitárias, propondo novas alternativas e tecnologias que ajudem a modificar a política existente. 
REIS, T.E. dos \& COSTA, V.C. da. Análise da vulnerabilidade na zona ...

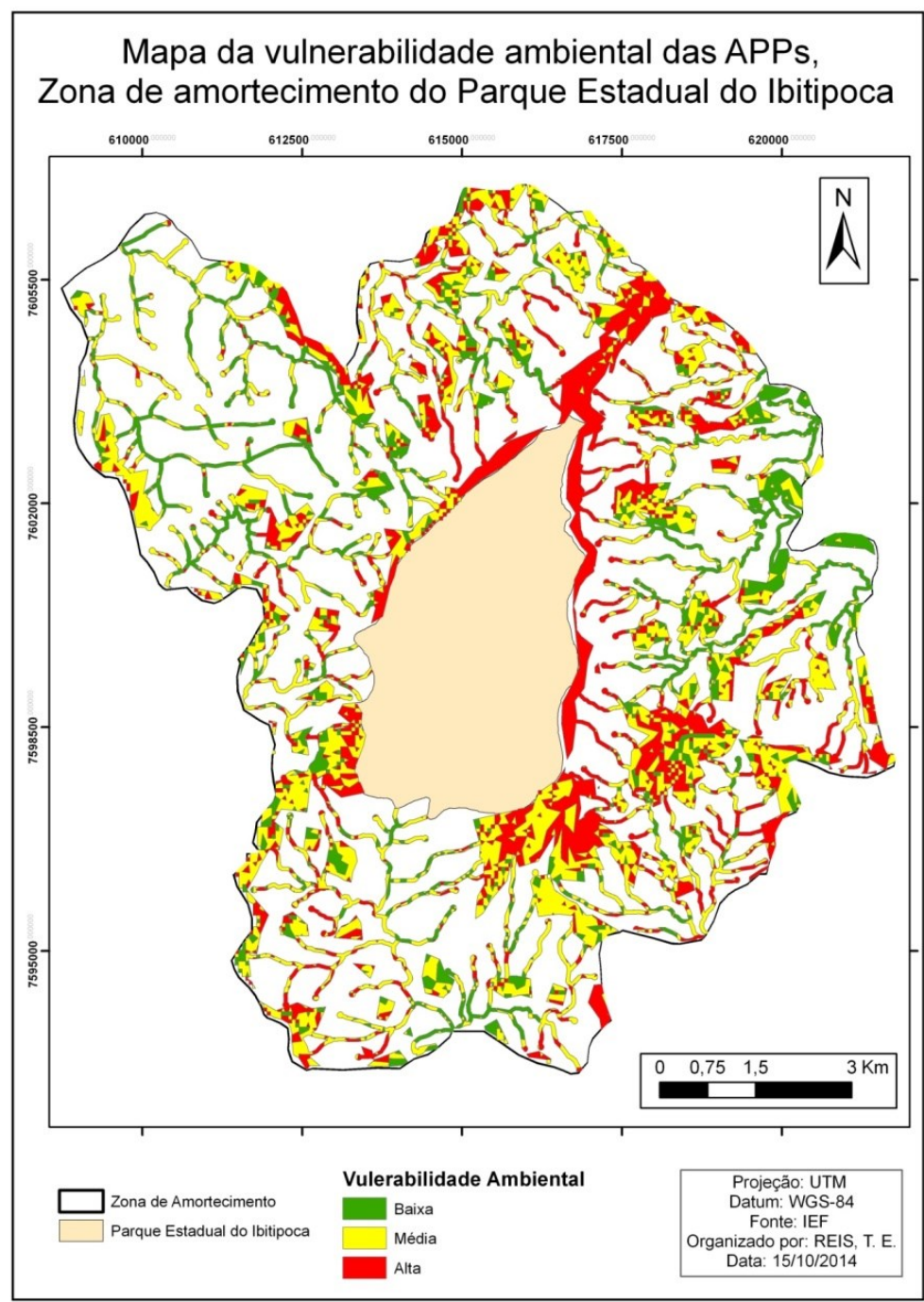

Figura 5: Mapa de Vulnerabilidade ambiental das APPs na zona de amortecimento. Fonte: IEF, 2010. 
REIS, T.E. dos \& COSTA, V.C. da. Análise da vulnerabilidade na zona ...

As ferramentas geotecnológicas, tais como o geoprocessamento, SIG, sensoriamento remoto e GPS, são importantes na gestão das UCs, pois permitem a interação e o manuseio de uma grande quantidade de dados, precisos e rápidos, obtidos com um alto grau de confiabilidade. Essas geotecnologias tornam o planejamento mais dinâmico e eficiente, auxiliando no gerenciamento, nas tomadas de decisões e nas avaliações das ações permitidas no Parque e na ZA.

Os resultados obtidos nesta pesquisa tornam-se ferramentas que poderão ser apropriadas na execução do novo plano de manejo. Os conhecimentos adquiridos representam uma contribuição para a gestão da Unidade de Conservação e seu entorno, assim como o banco de dados georreferenciado gerado e servirão de base para novos cruzamentos e análises ambientais sobre o PEI e sua ZA.

\section{Referências bibliográficas}

ACSELRAD, H. Ambientalização das Lutas Sociais - o caso domovimento por justiça ambiental. Estudos Avançados, São Paulo, v. 24, n. 68, 2010. Disponível em: http://www.scielo.br/scielo.php?script=sci_arttext\&pid=S010340142010000100010\&lng=en\&nrm=iso Acesso em: 20 abr. 2014.

ALVES, H. P. da F. Vulnerabilidade socioambiental na metrópole paulistana: uma análise sociodemográfica das situações de sobreposição espacial de problemas e riscos sociais e ambientais. Revista Brasileira de Estudos Populacionais, v. 23, n.1, 2006. Disponível em: http://www.scielo.br/scielo.php?script=sci_issuetoc\&pid=0102309820060001\&lng=pt\&nrm=iso Acesso em: 20 abr. 2014.

BEDIM, B. P. O processo de intervenção social do turismo na Serra de Ibitipoca (MG): simultâneo e desigual, dilema camponês no “Paraíso do Capital”. 2008. 397 f. Dissertação 
REIS, T.E. dos \& COSTA, V.C. da. Análise da vulnerabilidade na zona ...

(Mestrado em Geografia) - Instituto de Geociência, Universidade Federal de Minas Gerais, Belo Horizonte. 2008.

BRASIL. Lei $\mathrm{n}^{\circ}$ 6.766, de 19 de dezembro de 1979. Parcelamento do Solo Urbano. Brasília, DF, Senado, 1979. Disponível em: http://www.planalto.gov.br/ccivil_03/leis/16766.htm Acesso: 6 jul. de 2014.

. Resolução CONAMA n ${ }^{\circ} 13$, de 6 de dezembro de 1990. Dispõem normas referentes ao entorno das Unidades de Conservação. Brasília, DF, 1990. Disponível em: http://www.mma.gov.br/port/conama/res/res90/res1390.html Acesso: 04 jan. 2014.

Lei $\mathrm{n}^{\circ} .9 .985$, de 18 de julho de 2000 - Regulamenta o art. $225, \S 1^{\circ}$, incisos I, II, III, e VII da Constituição Federal, institui o Sistema Nacional de Unidades de Conservação da Natureza e dá outras providências. Brasília, DF, 2000. Disponível em: http://www.planalto.gov.br/ccivil_03/leis/19985.htm Acesso em: 4 jan. 2014.

- Resolução CONAMA n³03, 20 de março de 2002. Dispõe sobre parâmetros, definições e limites de Áreas de Preservação Permanente. Brasília, DF. 2002. Disponível em: http:/www.mma.gov.br/port/conama/res/res02/res30302.html Acesso em: 10 ago. 2014.

. Lei 12.651, de 25 de maio de 2012. Código Florestal.

Brasília, DF, 2012. Disponível em: http://www.planalto.gov.br/ccivil_03/_ato20112014/2012/lei/112651.htm Acesso em: 01 out. 2014.

LI, A.; WANG, A.; LIANG, S.; ZHOU, W. Eco-environmental vulnerability evaluation in mountainous region using remote sensing and GIS - a case study in the upper reaches of 
REIS, T.E. dos \& COSTA, V.C. da. Análise da vulnerabilidade na zona ...

Minjiang River, China. Ecological Modeling, v. 192, p. 175-187, 2006. Disponível em: http://www.files.scire.net.br/atrio/upegdls_upl/THESIS/53/dissertao_eugnio_noronha.pdf Acesso: 11 jun. 2014.

MILLER, K.R. Evolução do Conceito de Áreas de Proteção Oportunidades para o século XXI. In: I Congresso brasileiro de unidades de conservação, Curitiba, 1997. Anais... UNILIVRE. 1997. v. 1. p. 13-21

OLIVEIRA, G. C.; FILHO, E. I. F. Metodologia para delimitação de APPs em topos de morros segundo o novo Código Florestal brasileiro utilizando sistemas de informação geográfica. In: XVI Simpósio Brasileiro de Sensoriamento Remoto. Foz do Iguaçu, PR. Anais... Foz do Iguaçu, PR, 2013. Disponível em: http://www.dsr.inpe.br/sbsr2013/files/p0938.pdf Acesso: 03 ago. 2014.

PELUZIO, T. M. O.; SANTOS, A. R.; FIELDLER, N. C. Mapeamento de áreas de preservação permanente no ARCGIS 9.3. Alegre: CAUFES, 2010. Disponível em: http://www.mundogeomatica.com.br/MapeamentoAPPsArcGIS93. htm Acesso: em 20 ago. 2014.

RIBEIRO, M. F. Análise Ambiental aplicada à Definição da Zona de Amortecimento no Parque Estadual da Pedra Branca (Município do Rio de Janeiro, RJ), com base em Geoprocessamento. 2013. 440 f. Tese (Doutorado e Planejamento Energético), Universidade Federal do Rio de Janeiro. Rio de Janeiro, RJ. 2013.

RODELA, L. G.; TARIFA, J. R. O clima da Serra do Ibitipoca, sudeste de Minas Gerais. Revista GEOUSP - Espaço e Tempo, São Paulo, n.11, p. 101 - p. 113, 2002. 
REIS, T.E. dos \& COSTA, V.C. da. Análise da vulnerabilidade na zona ... UNIVERSIDADE FEDERAL DE VIÇOSA. Mapa de solos do Estado de Minas Gerais. Belo Horizonte: Fundação Estadual do Meio Ambiente, 2010.

Recebido em março de 2015 Aceito em maio de 2016 